\title{
S100A7 wt Allele
}

National Cancer Institute

\section{Source}

National Cancer Institute. S100A7 wt Allele. NCI Thesaurus. Code C143079.

Human S100A7 wild-type allele is located in the vicinity of 1q21.3 and is approximately 3 $\mathrm{kb}$ in length. This allele, which encodes protein S100-A7, plays a role in calcium binding, epidermal development and antimicrobial activity. Aberrant overexpression is associated with hyperproliferative skin diseases and mutations in the gene may be associated with melanoma and T-cell lymphoma. 